Dept. of Poultry Diseases,

Faculty of Veterinary Medicine, Beni-Suef University.

\title{
COMPARATIVE STUDIES BETWEEN INDIRECT HEMAGGLUTINATION (IHA) TEST AND ENZYME LINKED IMMUNOSORBENT ASSAYS (ELISA) TEST FOR DETECTION OF SERUM ANTIBODY LEVELS AGAINST INFECTIOUS BURSAL DISEASE (IBD) VIRUS IN COMMERCIAL BROILERS
}

(With 3 Tables and One Figure)

By

\section{AL-H.M. DAHSHAN and A.S. HUSSIEN*}

* Department of Virology, Faculty of Veterinary Medicine,

Beni-Suef University.

(Received at 19/7/2011)

مقارنة بين اختبار الاليزا واختبار تخثر الام الغير مباشر لتحديد مستوي

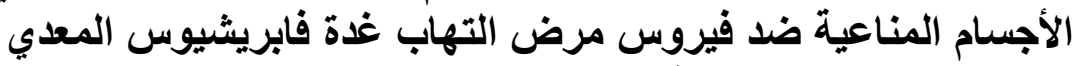
في قطعان التسمين مرن التين

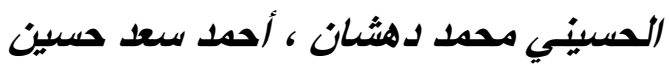

تم عمل مقارنة بين اختبار الاليزاو واختبار تخثر الدم الغير مبانر كتجربتين سيرولوجيتين

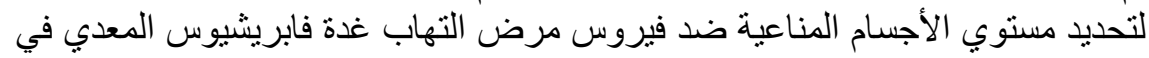

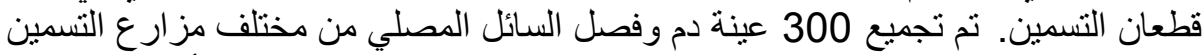

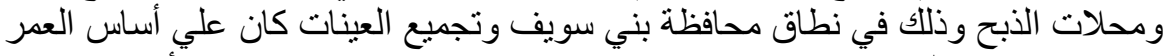

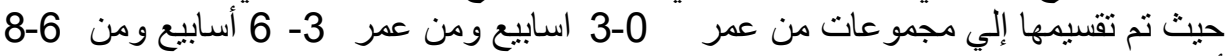

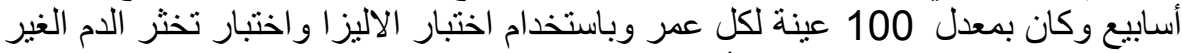

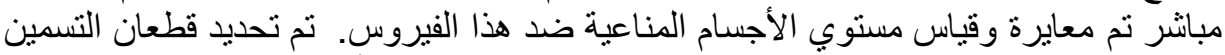

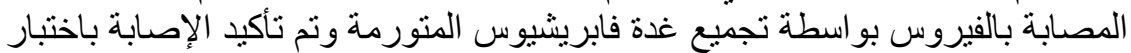

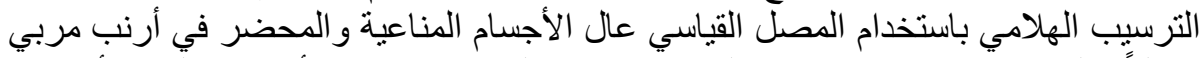

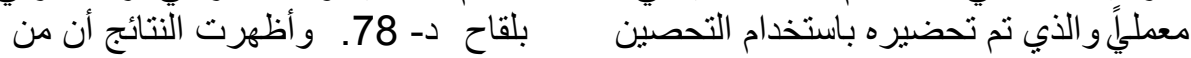

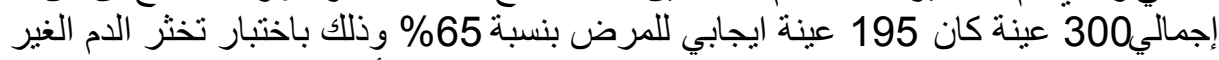

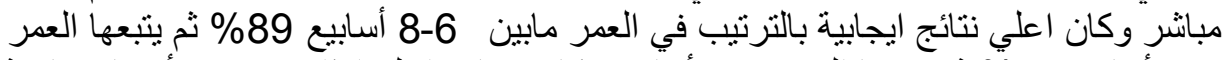

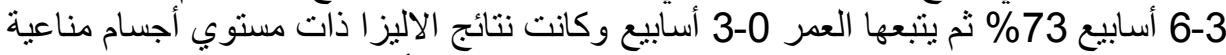

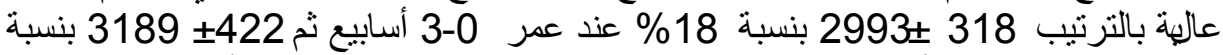
35 عند عمر 3-6 أسابيع ثم 455ـ 4225 بنسبة 69\% عند عمر 6-8 أسابيع وكان هناك 


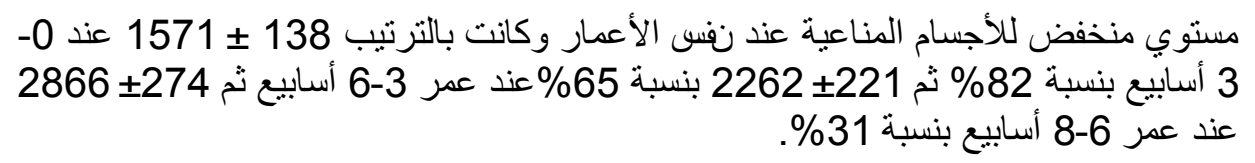

\section{SUMMARY}

This study was done to compare between IHA test and ELISA test as a serological test for detection of serum antibody levels against Infectious Bursal Disease Virus (IBDV) in Commercial Broilers, 300 Serum samples were collected from different commercial broiler farms and slaughter Shops from in and around Beni-suef Governorate. These samples were divided into three groups according to the age of the birds i.e. 0-3 weeks (100 samples), 3-6 weeks (100samples) and 6-8 weeks (100 samples).ELISA and Indirect Hemagglutination (IHA) test were used to titrate the serum antibodies against infectious bursal disease virus. Hyper immune serum was raised in laboratory rabbits against IBDV vaccine (D-78). It was used to identify and confirm the IBD virus from bursal tissues isolated from the IBD affected flocks using the qualitative tests i.e. agar gel precipitation suspension was prepared and used to determine the antibody titer. Results indicated that out of 300 test serum samples $195(65 \%)$ were positive. The maximum positive samples belonged to 6-8 weeks of age (89\%) followed by 3-6 weeks (73\%) and 0-3 weeks (33\%), respectively while the result of ELISA test of high and low titers were $18 \%$ and $82 \%$ at $0-3$ week of age then at age 3-6 weeks the high titers were $35 \%$ and low titers were $65 \%$ and finally high ELISA titers $69 \%$ and low titers $31 \%$ at age 6-8 weeks.

Key words: IHA test, ELISA test, serum antibodies, infectious bursal disease virus

\section{INTRODUCTION}

Infectious bursal disease (IBD) is an important viral disease in poultry industry primarily in broilers due to significant economic losses resulting from high mortality and immunosuppression. The disease is characterized by sudden onset, short course, extensive destruction of lymphocytes and profuse watery diarrhea, followed by death or rapid recovery (Lukert and Saif, 2003). It is of major concern due to its high morbidity and mortality rate during acute phase of infection or immunosuppression renders the birds more susceptible to other 
infections and also interferes with vaccination of other diseases when the chickens are infected at an early age, (Nakamura et al., 1992 and OIE, 2004). The disease has shown mortality as high as $23 \%$ in a few isolated outbreaks (Anjum et al., 1994). Morbidity is exhibited through increased processing plant condemnations, higher feed conversions and depressed average daily weight gain (Saif, 1991). Infectious bursal disease (IBD) is an acute, highly contagious disease of young chicks. It is caused by a dsRNA virus belongs to family Birnaviridae (Lukert and Saif, 1997). Day old progeny chicks are being sold by many hatcheries with unknown status of parental immunity against various prevalent infections particularly against IBD.

Rautenschlein et al. (2003) compared immunopathogenesis of mild, intermediate and virulent strains of classic IBDVs and showed that the most virulent strain induced the most prominent bursal damage and significant suppression of the mitogenic response and the mild vaccines induced no detectable lesions in the bursa.

Vaccination schedules followed at almost all farms become ineffective and therefore, commercial broilers remain vulnerable to the natural IBD infection due to the neutralization of live virus vaccine by maternal antibodies (Wood et al., 1981).

A number of sero diagnostic tests are available to diagnose the clinical cases including indirect hemagglutination (Aliev et al., 1990), agar gel precipitation (Castello et al., 1987), enzyme linked immunosorbent assay (Nicholas et al., 1985; Cao et al., 1995), counter immunoelectrophoresis (Hussain et al., 2002) and single radial hemolysis tests (Hussain et al., 2003). IHA test is considered to be inexpensive, quick and easy to perform (Rahman et al., 1994). The present study was conducted for detection of antibodies against Infectious bursal disease virus and makes a comparison between two serological methods. The main objective of the work was to establish the prevalence of antibodies against IBD in different age groups of broiler birds.

\section{MATERIALS and METHODS}

\section{1- Serum samples:}

A total of 300 blood samples were collected from different commercial broiler farms and slaughter shops in and around Beni-suef Governorate in clean dry, sterile wesserman tubes. The tubes containing blood samples were left in horizontal position for an hour at room 
temperature and then left for another hour at $4{ }^{\circ} \mathrm{C}$ then centrifuged at 3000 r.p.m. for 15 minutes. Serum samples were carefully separated in a small Eppendorf vials, all the serum samples were heat inactivated at 56 ${ }^{\circ} \mathrm{C}$ for $25-30$ minutes in a water bath (Rahman et al., 1994) and then processed for laboled and kept at $-20^{\circ} \mathrm{C}$ till used in AGPT, ELIZA and IHA.

\section{2- Embryonated chicken eggs (ECE):}

Specific pathogen free (SPF) ECE were obtained from Ministry of Agriculture and cultivation of lands, production of SPF embryonated eggs project Kom-Oshim, Fayoum. ECE were used for isolation IBDV strain through chorioallantoic membrane (CAM) route of inoculation.

\section{3- Isolation of the Virus:}

Infected bursae were collected from IBDV affected birds, weighed and chopped; PBS ( $\mathrm{pH} 7.2$ ) was added to prepare $10 \%(\mathrm{w} / \mathrm{v})$ suspension and mixed thoroughly by using homogenizer. The sonicated antigen was centrifuged at 5000 r.p.m for 15 minutes and the supernatant was collected.

\section{4- Hyper-immune serum:}

The hyper-immune was raised in rabbits against commercial IBDV vaccine (D-78) (Barnes et al., 1982).

\section{5- AGPT Test:}

BDV (field isolate) was confirmed using the agar gel precipitation (AGPT) (Castello et al., 1987) test using the above raised hyper immune serum.

\section{6- Indirect Hemagglutination (IHA) test - Washing and Coating of Erythrocytes:}

$5.0 \mathrm{ml}$ of Human blood group "O" was collected aseptically in a disposable syringe and transferred to a glass already containing $1 \mathrm{ml}$ of Sodium citrate (4\% Solution) as an anticoagulant. The blood was centrifuged at $1500 \mathrm{rpm}$ for 15 minutes. The plasma and buffy coat was removed. Washing RBCs with phosphate buffered saline (PBS) were used for sensitization with antigen. For sensitization, $2 \mathrm{ml}$ antigen and 1 $\mathrm{ml}$ of washed RBCs in $2 \mathrm{ml}$ of PBS were mixed and placed in the incubator, at $37^{\circ} \mathrm{c}$ for 45 minutes (Rahman et al., 1994). The treated erythrocytes were washed with PBS to remove excessive antigen. Finally, one percent suspension of sensitized RBCs was used in indirect hemagglutination test. 


\section{Test Procedure:}

The test was performed according to the method of Aliev et al. (1990) and Rahman et al. (1994). Briefly, after making two fold serial dilution of the test serum, equal quantity of sensitized human "O"RBCs (1\%) were added to each well. The plates were gently tapped to ensure even dispersion of erythrocytes and then kept at $37^{\circ} \mathrm{C}$ for 30 minutes of incubation in comparison with the negative control which contain physiological saline and sensitized RBCs. Degree of agglutination in each row was recorded. The serum samples caused a distinct erythrocytic agglutination resulting in characteristic reticulum settling of RBCs throughout the bottom of the well was considered positive. The samples showing peculiar central button- shaped settling of RBCs were recorded as negative. The IHA titer of each sample was narrated as the reciprocal of its end point dilution.

\section{7- IBD ELISA Kits:}

IBDV-ELISA Kits were obtained from Kikegaard and Perry laboratories $(\mathrm{Kpl})$, U.S.A.

\section{8- ELISA test procedures:}

ELISA test was carried out according to manufactural instructions as while

\section{Calculation of ELISA titers:}

- Negative control mean $(\mathrm{NCx})=$ well $\underline{\mathrm{A} 1+\text { well } \mathrm{A} 2}=\mathrm{NCx}$

$$
2
$$

- Positive control mean $(\mathrm{PCx})=\underline{\text { well } \mathrm{A} 3+\text { well A4 }}=\mathrm{PCx}$

$$
2
$$

$-\mathrm{S} / \mathrm{P}$ ratio

$$
=\frac{\text { sample mean }-\mathrm{NCx}=\mathrm{S} / \mathrm{P}}{\mathrm{PCx}-\mathrm{NCx}}
$$

-Titer- Relates $\mathrm{S} / \mathrm{P}$ at a 1:500 dilution to an endpoint titer: $\log 10$ titer=1.09( $\log 10 \mathrm{~S} / \mathrm{P})$

\section{9- Statistical analysis:}

Statistical Analysis of variance (ANOVA) test was used to estimate differences among treatments according to (Steel and Torrie 1960). Correlation and linear regression analysis were also performed using Microsoft excel program.

\section{RESULTS}


Table 1: Serum samples showing positive or negative IHA results

\begin{tabular}{|c|c|c|c|c|}
\hline Age (Weeks) & $\begin{array}{c}\text { Total } \\
\text { Samples }\end{array}$ & $\begin{array}{c}\text { No. of Positive } \\
\text { Samples }\end{array}$ & $\begin{array}{c}\text { No. of Negative } \\
\text { Samples }\end{array}$ & $\begin{array}{c}\text { Positive } \\
\text { percentage }\end{array}$ \\
\hline 0-3 wks & 100 & 33 & 57 & $33 \%$ \\
\hline $3-6 \mathrm{wks}$ & 100 & 73 & 27 & $73 \%$ \\
\hline 6-8 wks & 100 & 89 & 11 & $89 \%$ \\
\hline Total & 300 & 195 & 112 & $65 \%$ \\
\hline
\end{tabular}

Table 2: Distribution of birds on the basis of IHA titer

\begin{tabular}{|c|c|ccccccc|c|}
\hline $\begin{array}{c}\text { Age } \\
\text { (weeks) }\end{array}$ & $\begin{array}{l}\text { No. of } \\
\text { Positive } \\
\text { Samples }\end{array}$ & \multicolumn{6}{|c|}{ Antibody titer using indirect hemagglutination test } & GMT \\
\hline $0-3$ wks & 33 & 3 & 12 & 10 & 8 & - & - & - & 5.88 \\
\hline $3-6$ wks & 73 & - & 25 & 8 & 4 & 36 & - & - & 12.32 \\
\hline $6-8$ wks & 89 & - & 33 & 21 & 13 & 12 & 6 & 4 & 14.66 \\
\hline
\end{tabular}

Table 3: Mean ELISA antibodies titers

\begin{tabular}{|c|c|c|c|c|c|c|}
\hline \multirow{2}{*}{$\begin{array}{c}\text { Age } \\
\text { (Weeks) }\end{array}$} & \multicolumn{6}{|c|}{ Mean ELISA antibodies titers } \\
\cline { 2 - 7 } & $\begin{array}{c}\text { Mean high titers } \\
\text { No. of } \\
\text { high titers }\end{array}$ & $\begin{array}{c}\text { \% of high } \\
\text { titers }\end{array}$ & titers & $\begin{array}{c}\text { No. of low } \\
\text { titers }\end{array}$ & $\begin{array}{c}\% \text { of low } \\
\text { titers }\end{array}$ & Titers \\
\hline 0-3 wks & 18 & $18 \%$ & 2993 & 82 & $82 \%$ & 1571 \\
& 35 & $35 \%$ & $\begin{array}{c}3189 \\
\pm 318\end{array}$ & 65 & $65 \%$ & \pm 138 \\
\hline $3-6$ wks & 69 & $69 \%$ & $\begin{array}{c}4225 \\
\pm 455\end{array}$ & 31 & $31 \%$ & 2262 \\
& & & & & & \pm 221 \\
\hline 6-8 wks & 69 & & & & \\
& & & & & & \\
\hline
\end{tabular}




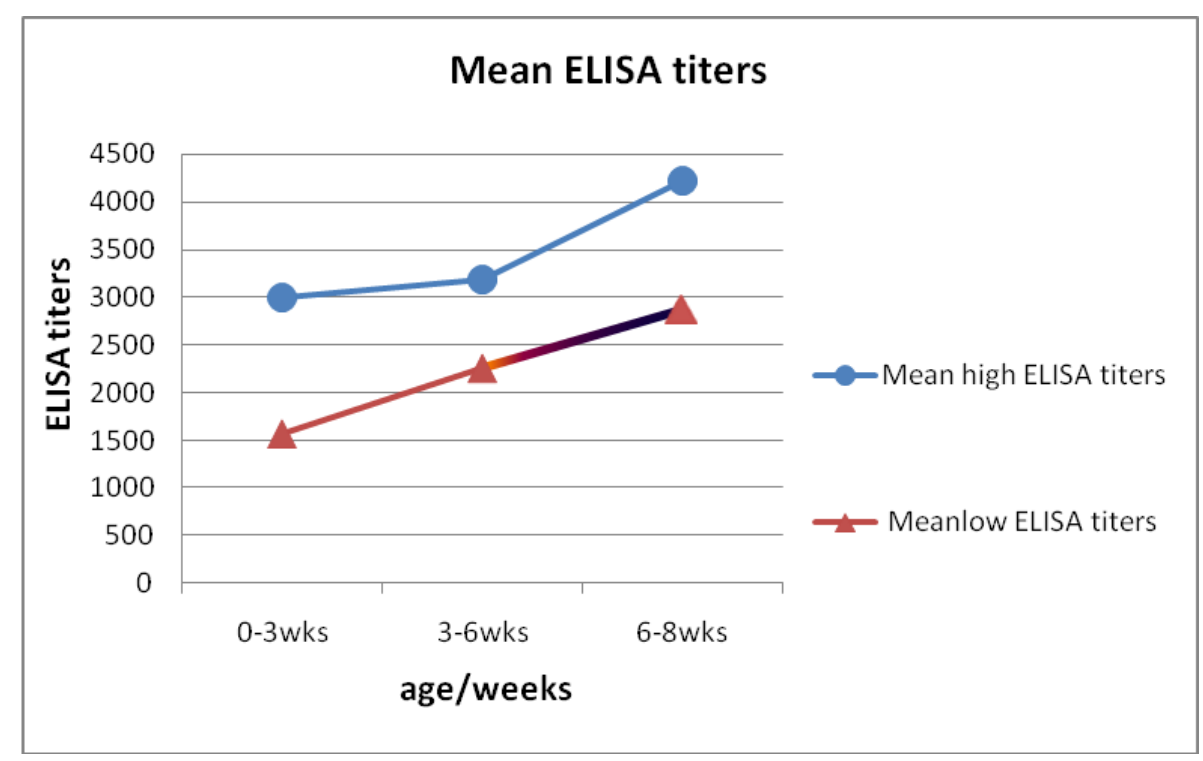

Fig. (1)

\section{DISSCUSION}

Serum antibodies against infectious bursal disease virus can be detected using a number of sero diagnostic tests both qualitatively and quantitatively (Cullen and Wyet, 1975). A total of 300 serum samples were collected from different commercial broiler farms and shops, which were subjected to indirect hemagglutination test and ELISA test. In IHA test 195 were found positive out of the 300 serum sample, with the overall positive percentage of $65 \%$ (Table 1). In broiler birds ranging from 0-3 weeks of age, out of 100 serum samples 33 were found positive, the positive percentage of this group was $33 \%$ (Table 1). And in comparison with the result of ELISA test found that high titers were 18 out of 100 serum samples with percentage of $18 \%$ and low titers $82 \%$ (Table 3) and IHA antibody titer varied from 1:2 to 1:16 with a geometric mean titer of 5.88 as described in (Table 2). The results showed that the serum antibody levels were too low to protect the birds from the infectious bursal disease infection due to low levels of maternally derived antibodies (MDAs) which are transmitted from the dam to the chicks through yolk and protect the chicks from the harmful effects of IBDV in early ages (Lukert and Saif, 1997). The titer of $\log 6$ (1:64) is considered to be protective and gave specific immunity (Lukert 
and Saif, 1997) but in the present study the overall titer of birds of 0-3 weeks of age, were found between 1:4 and 1:16 which rendered the birds to sub clinical form of IBDV infection which leads to immunosuppression.

Out of total 100 serum samples collected from 3-6 weeks old birds, 73 were found positive with a positive percentage of $73 \%$ (Table 1). IHA antibody titer varied from 1:4 to 1:32 with a geometric mean titer of 12.32 as shown in (Table 2). The result of ELISA test found high titers were 35 out of 100 serum samples with percentage $35 \%$ and low titers were $65 \%$ the results of this group indicated higher antibody levels than the previous group which may be due to the presence of infectious agent in the environment or the result of vaccination. Antibody levels of this group were still lower from the expected one. Approximately 10-12 days are required after vaccination to develop minimal protective titer during this "lag time" chickens are susceptible to the infection (Lukert and Saif, 1997). As severity of the infection is directly related to the susceptible cells present in the bursa therefore, this group is more prone to clinical infection as bursa of Fabricious is at its maximum development (Saif, 1991). In broiler birds ranging in age from 6-8 week, out of 100 serum samples, 89 were found positive, with a positive Degree of percentage of $89 \%$ (Table 1). IHA antibody titer varied from 1:4 to $1: 128$. Geometric mean titer of this group was 14.66 (Table 2). With high ELISA titers 69\% and low titers $31 \%$.Birds of this group were having higher antibody levels than the previous two groups and showed relatively decreased susceptibility to clinical infection (Saif, 1991). Among the possible reasons for this low level of IHA and ELISA antibodies titers in commercial broilers i.e. specific immunity in vaccinated birds, these may be related to the vaccines and vaccination (Sil et al., 2002). It has been observed that with emergence of new variants, the classical vaccines are no more effective to control the disease (Tariq, 1999). The emergence of "very virulent" (vv) strains of IBDV, which can cause up to $70 \%$ flock mortality in laying pullets (Chettle and Wyeth 1989; van den Berg and Meulemans, 1991), are antigenically similar to the "classical" strains, (Eterradossi et al., 1992). Remarkably, however, vvIBDV can establish infection in the face of levels of maternally derived antibodies that were previously protective against "classical" strains. While, vvIBDV infections also have been observed in Africa, Asia and, only recently, in South America 
(Ikuta et al., 2001). Poor vaccine quality is a common problem in developing countries and could be the result of poor manufacturing standards, lack of adequate storage facilities, application of expired vaccine batches and vaccine handling during transportation (Vui et al., 2002). Exposure to viricidal agent like phenol or alcohol and improperly disinfected syringes might have detrimental effects on virus viability. Birds receiving continuous treatment with chloramphenicol or furazolidone have been shown to have impaired immune response (Tariq, 1999). Presence of mycotoxins in the feed reduces the host immunity directly as give poor output in immunity development. Mycotoxin indirectly affects the immunity by producing steroids from the adrenal glands which decrease the lymphocytes leading to immunosuppression (Tariq, 1999). Heat stress and water deprivation also lead to production of steroids and thus resultantly immunosuppression (Sil et al., 2002). Poor nutrition like hypoproteinemia may hurt the immune response (Tariq, 1999). Ammonia present in the farm is a water soluble gas. If it goes above 30 ppm, badly affects the moist mucus membranes of the gut, trachea and nostrils leading to the decreased local immunity i.e. decreased $\operatorname{IgA}$ (Tariq, 1999). Another weak point might be the quality of water to dilute the vaccine before application. Unsuitable vaccination schedule also lead to the neutralization of MDAs and resultantly making the birds more susceptible to the infection. The half life of the maternal antibodies to IBDV is between 3 and 5 days (Lukert and Saif, 1997) therefore, the exact antibody titer should be known to determine the age at which the chick will be susceptible to IBD. The antibody titer must not fall below 1:64 before chickens can be vaccinated efficiently (Lukert and Saif, 1997). In the present study, most of the birds had antibody titer below 1:64 and 1:128 which showed the lack of specific immunity and relative susceptibility to the infection. All the facts relating to the low antibody titers in broiler birds showed that the local field IBDV can even break through the MDAs and are antigenically different from vaccinal strains as evident from the lack of specific immunity i.e. IBD field outbreaks even after vaccination. So it is suggested that strategies must be developed to make the vaccine against the local field IBD virus isolates for the implementation of better disease control program in the country

\section{REFERANCES}


Aliev, A.S.; Dzhavadov, E.D. and Leont'eva, M.M. (1990): Indirect Hemagglutination test for infectious bursal disease of fowls. Vet. Bull., 60: 47-67.

Anjum, A.D.; Sabri, G.S. and Jamshidi, K. (1994): Occurrence spread and control of infectious bursal disease in Pakistan. In Proceedings of 1st PPAPVMA Punjab, International Poultry Conference March 30 - April 01, pp: 57-59.

Barnes, H.J.; Wheeler, J. and Reed, D. (1982): Serological evidence of infectious bursal disease virus infection in IOWA turkeys. Avian Dis., 26: 560-565.

Cao, Y.C.; YingZuo, B.I. and Zhu JiMei, (1995): Application of enzymelinked immuno-sorbent assay for evaluation of immunological efficiency of chicks against IBD. Chinese J. Vet. Med., 21: 9-10.

Castello, L.; Martinez, B.L. and Heronodez, K. (1987): Comparison of the agar gel precipitation, virus neutralization and enzymelinked immunosorbent assay in the determination of antibodies to infectious bursal disease virus. Veterinaria-Mexico, 18: 317-323.

Chettle, N.J. and Wyeth, P.J. (1989): Outbreak of virulent Infectious bursal disease in East Anglia. Vet. Rec. 125: 271-272.

Cullen, G.A. and P.J. Wyet, (1975): Quantitation of antibodies to infectious bursal disease. Vet. Rec., 93: 315.

Eterradossi, N.; Picault, J.P.; Druin, P.; Michele Guittlet; Rolande L'hospitalier, and Bennejean, G. (1992): Pathogenicity and preliminary antigenic characterization of 6 infectious bursal disease virus strains isolated in France from acute outbreaks. J. Vet. Med. B., 39: 683-691.

Hussain, I.; Nisar, A.; Rahman, S.U.; Mehmood, S.; Zahoor, A.; Ashfaque, M.; Mehmood, S. and Akhtar, M. (2002): Counterimmunoelectrophoresis-A rapid test for the detection and quantification of infectious bursal disease virus. Proc. (Abst). Regional Seminar on Prevalent and Newly emerging Poultry disease held on April 15-16, at University of Agriculture Faisalabad.

Hussain, I.; Zahoor, M.A.; Mehmood, M.S. and Akhtar, M. (2003): Single radial hemolysis technique in comparison with indirect 
hemagglutination and agar gel precipitation tests for assaying antibodies against infectious bursal disease virus. Pak. J. Life Soc. Sci., 1: 62-64.

Ikuta, N.; El-Atrache, J.; Villegas, P.; Garcia, M.; Lunge, VR.; Fonseca, ASK.; Oliveira, C. and Marques, EK. (2001): Molecular characterization of Brazilian Infectious Bursal Disease Viruses. Avian Diseases; 45 (2): 297-306.

Lukert, P.D. and Saif, Y.M. (1997): Infectious bursal disease. In: Calnek, B.W., Barnes, B.W., Beard, C.W., McDougald, L.R., Saif, Y.M. (Eds.), Diseases of Poultry. 10th ed. Iowa State University Press, Ames, pp. 721-738.

Lukert, P.D. and Saif, Y.M. (2003): Infectious bursal disease. In: Y.M. Saif (Ed.) Disease of Poultry.11th Ed., Iowa State University, Ames, Iowa, USA, pp: 161-179.

Nakamura, T.; Otaki, Y. and Nunoya, T. (1992): Immunosuppressive effect of a highly virulent Infectious bursal disease virus isolated in Japan. Avian Dis., 36: 891-896.

Nicholas, R.A.J.; Reed, N.E.; Wood, G.W.; Herbert, C.N.; Muskett, J.C. and Thronton, D.H. (1985): Detection of antibodies against Infectious bursal disease virus: a comparison of three serological methods. Res. In Vet. Sci., 38: 189-192.

OIE (2004): Manual of recommended diagnostic techniques and requirements for biological products for lists $\mathrm{A}$ and $\mathrm{B}$ diseases. Office International Des Epizootes.

Rahman, S.U.; Ashfaque, M. and Javed, S. (1994): Infectious bursal disease virus antibody titration using indirect Hemagglutination test. Pak. Vet. J. 14: 101-103.

Rautenschlein, S.; Yeh, H.Y. and Sharma, J.M. (2003): Comparative immunopathogenesis of mild, intermediate, and virulent strains of classic infectious bursal disease virus. Avian Diseases 47: 66-78.

Saif, Y.M. (1991): Immunosuppression induced by infectious bursal disease virus. Vet. Immunol. Immunopath, 30: 45-5.

Sil, G.C.; Das, P.M.; Islam, M.R. and Rahman, M.M. (2002): Management and disease problems of Cockrels in some farms of Mymensingh, Bangladesh. Int. J. Poult. Sci., 1: 102-105.

Steel, R.G.D. and Torrie, J.H. (1960): Principles and procedures of statistics. McGraw-Hill Book Comp. Inc. New York, Toronto, London, pp. 99-131.

Tariq, J. (1999): Vaccines and Vaccination. AVN, Sep. 25, pp: 22-23. 
Van Den Berg, T.P. and Meulemans, G. (1991): Acute infectious bursal disease in poultry protection afford by maternally derived antibodies and interference with live vaccination.Avian Pathol., 20, 3: 409-421.

Vui, T.Q.; Lohr, J.E.; Kyule, M.N.; Zessin, K.H. and Baumann, M.P.O. (2002): Antibody levels against Newcastle disease virus, Infectious bursal disease virus and Influenza virus in rural chicks in Vietnam. Int. J. Poult. Sci., 1: 127-132.

Wood, G.W.; Muskett, J.C. and Thornton, D.H. (1981): The interaction of live vaccine and maternal antibody in protection against infectious bursal disease. Avian Pathol., 10: 365-373. 